\title{
The Effect of Different Corporate Market Capitalizations in International Portfolio Strategy in Eleven Asian Countries
}

\author{
Kuo-Hao Lee ${ }^{1}$ \\ ${ }^{1}$ Department of Finance, College of Business, Bloomsburg University of Pennsylvania, Bloomsburg, PA17815, SA, \\ USA \\ Correspondence: Kuo-Hao Lee, Department of Finance, College of Business, Bloomsburg University of \\ Pennsylvania, Bloomsburg, PA17815, SA, USA. Tel: 1-570- 389-5019. E-mail: klee@bloomu.edu
}

Received: July 9, 2013

Accepted: July 30, 2014

Online Published: August 1, 2014

doi:10.5430/afr.v3n3p107

URL: http://dx.doi.org/10.5430/afr.v3n3p107

\begin{abstract}
The study proved that the manners of returns generated from Large-, Mid- and Small- Cap stocks in 11 Asia countries are different and should not be ignored by international portfolio investors. We found that Asian Mid-Cap and Small-Cap markets indices have low correlations with both World market indices and among Cap market indices themselves; while Large-Cap funds have high correlations including amongst each other. Investors can obtain additional gains from international diversification if they consider including Mid- and Small-Cap stocks in their portfolio in Asian countries.
\end{abstract}

Keywords: Portfolio, International diversification, Market correlation, Asia capital market, Developed market

JEL classification: G11

\section{Introduction}

With world markets becoming more and more interdependent, international portfolio managers are beginning to look for ways to better diversify away the correlated risk among these interdependent markets. Among many other reasons, portfolio managers prefer Large-Cap stocks as opposed to other smaller cap-sized stocks believing that Large-Cap stocks provide a greater defense against systematic risk. However, if managers believe that correlations between markets are best reduced by Large-Cap stocks, they may be mistaken. This research provides evidence to support the use of Mid- and Small-Cap stocks for the purpose reducing the correlation between these interdependent markets in Asia countries.

Classic portfolio studies from Grubel (1968), Levy and Sarnat (1970), and Solnik (1974) documented that the gains from international diversification was based on the premise that the correlation was relatively lower among international securities than domestic securities. Continuing liberalization of capital market of Asian countries in recent decades and their increasing cross border investments and international trades made the regional business integration even faster during recent years. The rapid change of business phenomenon and capital markets in Asian region have lead to a remarkable transformation in correlations between these Asian markets, where in the underpinnings of traditional international portfolio studies must be revised. We especially urge to find out how this will change the circumstances in Asia since the current commerce trend has been transiting to Asia.

Recent studies have raised challenges that higher international correlations clearly throw doubt on the efficiency of international diversification argued by those classic international diversification studies. Longin and Solnik (1995) documented that international stock markets indices correlated among each other have increased between the period of 1960 to 1990. Goetzmann, Lingfeng, and Rouwenborst (2005) stated during periods of higher economic and financial integration period that international stock markets tend to have higher correlations than normal times.

Large-Cap stocks have received the lion's share from international investors' diversification portfolios. The bias of Large-Cap stocks was because investors naturally gravitated to stock securities, in particular ones with good reputation as well as large foreign companies that are well known and most likely multinational. Kang and Stulz (1997) in their study of foreigners' equity holdings in Japan found that foreign investors prefer large, export oriented, liquid, and U.S. cross-listed firms. Another study from Ferreira and Matos (2006) showed that institutional investors strongly prefer large and liquid stocks with good governance practices too. Moreover, the same study points out institutional investors who prefer stocks which are cross-listed in the U.S. market and members of the MSCI (Morgan Stanley Capital International) all-country world index. The other factor that reinforces the Large-Cap bias was that most of cross-listed stocks were the Large-Cap stocks, and they also act as a stimulation of international investment. Foerster and Karolyi (1999) documented that the cross-listings of shares were often used by companies in order to enhance the level of investor recognition and expand the shareholder base. In Huberman (2001), the 
Large-Cap bias mostly acts in accordance with the proposition that familiarity breeds investment. Domestic institutional investors especially tend to track home stock market, which would build up the Large-Cap bias, since the national market indices are dominated by Large-Cap stocks also.

Returns from Large-Cap stocks are mainly affected by common international factors. On the other hand, returns from Mid- and Small-Cap stocks are mainly affected by local and idiosyncratic factors, especially in Asia market. This phenomenon occurs because, Large-Cap companies are more likely to be the international companies with higher chance to be exposed to international customers and be driven by the global trend; while the Mid- and Small-Cap companies tend to be more locally oriented and with more limited international exposure. Brooks and Del Negro (2006) recent study showed that an increase in the international component of a firm's sales will increase (decrease) the exposure of the firm to global (country-specific) shocks. This finding indicated that multinational firms were more subject to global shocks than locally oriented firms. The benefit of diversification of international portfolios with Large-Cap stocks can be modest since the returns of those companies are primarily affected by common global factors. However, the same result may not be applied to Mid- and Small-Cap stocks since their returns are mainly affected by local and idiosyncratic factors. Hence, Mid- and Small-Cap stocks become a potential factor and should be introduced into international portfolio in order to help investors gain more benefit from diversification.

Eun et al (2008) showed that the importance of diversification from Mid- and Small-Cap stock to the international portfolio investors. On the other hand, from the practical business world point of view, many investment companies-such as Fidelity, ING, Lazard, Merrill Lynch, Morgan Stanley, Oppenheimer, and Templeton-currently offer Small-Cap oriented international mutual funds in the U.S. In terms of geographical coverage, some funds are global as well as international, while others are regional and national. These recent introductions of international Mid- and Small-Cap funds are highly instructive and also suggested the unique role that Mid- and Small-Cap stocks can play in global risk diversification.

Asian capital markets have been flourishing during recent decades and quickly become one of the crucial elements for international investors to form their investment portfolio strategy. The behavior of different Caps stocks have been investigated and found out that the difference of their correlation manners. We wanted to further develop this research to see how these different Caps Stocks factors will be acting in newly strong growing Asian capital markets. The main purpose of this research is to show that the behavior of returns generated from Large- , Mid- and Small-Cap stocks in Asian markets are different and should not be ignored by international portfolio investors.

\section{Data and Basic Statistics}

In this study, we aim to access the potential benefits that can be gained from diversification of international portfolios if the investors include Mid-Cap and Small-Cap stock. We study from the perspective of U.S. investors who invest international portfolios with MSCI country or Large-Cap indices but desire to obtain the gain of including Mid- and Small-Cap market indices from foreign countries.

We considered 11 countries in Asia: Hong Kong, Japan, Singapore, China, India, Indonesia, Korea, Malaysia, Philippines, Taiwan and Thailand. In order to maintain analytical tractability and consistency with industry practices, we examine the country indices and three market capitalization-based market indices, such as Large, Median and Small-Cap market indices from each country in our sample. In addition, we computed daily returns over most recent 5-year period from September 14, 2007-September 13, 2012. Our research contains two parts. First, we analyzed the difference of behaviors between returns that generated from country indices, Large, Median, and Small-Cap market indices, and we examined the correlation within each other plus their implications for diversification. Second, we applied the mean-variance analysis of international portfolio in introducing cap-based market indices.

From the data, we found that Mid-Cap and Small-Cap market returns have relatively low correlations with each other than Large-Cap market returns (Table 1: correlations). For example, during our sample period, the results showed that the correlation within the Hong Kong and Japan Large-Cap market returns is 0.527 while the correlation between the Small-Cap market returns from those two countries is 0.457. 38 out of 55 Large Cap correlations are higher than Small Cap correlations between 11 countries.

Further, the result showed that seven out of eleven countries have higher correlation between Large-Cap market returns with the World market returns than the correlation between Small-Cap market returns and the World market returns. For instance (Table 2: Basic Statistics), the correlation between the Hong Kong Large-Cap market returns with the World market returns is 0.457 , and the correlation between Hong Kong Small-Cap market returns with the World market returns is 0.392 . The same results also indicated for the U.S. Country market returns. From the prospective of U.S. investors, seven out of eleven Asia countries, except Indonesia, Korea, Malaysia and Philippines, have lower correlations between Small-Cap market returns and U.S. Country market returns than Large-Cap market returns and U.S. Country market returns. 
From above, our data result implies that Small-Cap market returns have lower correlations with the World market returns and U.S. Country market returns than Large-Cap market returns have with the World and U.S. Country market returns. This indicates that Small-Cap market returns are relatively less affected by global factors than Large affected by the same factors.

\section{Preliminary Analysis}

In order to compare the performance of these cap-base market indices, we obtained the daily MSCI stock market indices of the world and fourteen countries during the period September 14, 2007-September 13, 2012. We then evaluated the daily returns from the indices by using the following formula:

$$
R_{t}=\frac{\text { Index }_{t}-\text { Index }_{t-1}}{\text { Index }_{t-1}}
$$

We also assumed that in these eleven countries we studied the investors would not have to face any interruptions such as government, politics, personal, or closed market.

We calculated the mean, standard deviation, skewness, and kurtosis of daily returns for each cap-based market indices and the correlation of cap-based market returns with U.S. Country market returns (corr us) and with World market returns (corr w). Further, we conduct the basic T-tests to compare the difference of mean returns, the result showed that there is no significant difference in Large-Cap and Small Cap for all eleven Asia countries.

As for the volatility, ten out of eleven countries, except Malaysia, the Small-Cap market returns have lower volatility than the Large-Cap market returns. Among all the Large-Cap market returns, the lowest volatility is computed from the Malaysia market indices. We also noticed that in six out of eleven countries, the Large-Cap market returns have the highest correlation with the U.S. countries market indices (corr us). Using Hong Kong as an example, the correlation is 0.249 from Large-Cap market returns with U.S. country market returns, 0.154 from the Mid-Cap market returns and 0.165 from the Small-Cap market returns. Five exceptions are Japan, Indonesia, Korea, Malaysia and Philippine. The correlations between Japan and the U.S. country market indices are very low, regardless if it is from the Large-Cap market returns (0.006), Mid-Cap market returns (0.022), or Small-Cap market returns (0.006). The correlations between US Country market returns and Small-Cap market returns of these two countries still have lower correlations with U.S. Country market returns than the Large-Cap market returns.

As for the correlations with the World market returns, we denoted as "corr W", a similar result appeared. We can conclude that more than half of the Asia countries, Small-Cap market returns have lower correlations with U.S. Country market returns or the World market returns than Large-Cap market returns.

\begin{tabular}{lcc}
\hline \hline \multicolumn{3}{c}{ Number of countries with largest correlations from each capitalization } \\
\hline & Asian stocks and World Market & Asian Stocks and US market \\
\cline { 2 - 3 } Large-Cap & 6 & 6 \\
Mid-Cap & 3 & 4 \\
Small-Cap & 2 & 1 \\
\hline
\end{tabular}

\section{Methodology and Results}

\subsection{Mean-Variance Spanning Tests: Do Small-Caps Act Differently from Large-Caps?}

We first constructed a hypothesis test to check if the Small-Cap market returns can be spanned by all MSCI country indices. After the spanning test, we then examined the returns that generating from market-based indices and their risks affected by factors of global, local or Idiosyncratic.

Even though more than half of the Asia countries with the Mid-Cap and Small-Cap market returns have lower correlations with U.S. Country market returns or World market returns compared with the Large-Cap market returns, the Small-Cap market returns may still be spanned by the countries market returns. If that is true, then the gain of diversification of introducing Small-Cap market returns into the international portfolio will be less significant. On the other hand, if the spanning test has been rejected, then introducing Small-Cap market returns may improve the minimum-variance frontier base international portfolio.

Using the study by Huberman and Kandel (1987) and Kan and Zhou (2008), we constructed a spanning test to examine of Small-Cap market returns can be spanned by MSCI country indices or not. In order to do so, we built a regression model of the Small-Cap market returns ("new risk asset") on the MSCI countries indices ("benchmark assets") as following:

$$
R_{i}=\alpha_{i}+\beta_{i}^{H K} M S C I^{H K}+\cdots+\beta_{i}^{T H} M S C I^{T H}+\varepsilon_{i}
$$


where $\mathrm{R}_{\mathrm{i}}$ represent the return computed from Small-Cap market returns of the i-th country, MSCI ${ }^{\mathrm{HK}}$ denotes the return on the MSCI Hong Kong country index, $\alpha_{\mathrm{i}}$ represent the estimated regression intercept of the Small-Cap market returns, and $\beta_{i}^{H K}$ is the estimated regression coefficient associated with MSCI Hong Kong.

The null hypothesis of the spanning test is equivalent to the joint hypothesis that the regression intercept is equal to zero and the sum of all the regression coefficients is equal to one:

$$
\alpha_{i}=0, \quad \text { and } \sum_{i} \beta_{i}=1
$$

We assumed that the null hypothesis is true, $\sum_{i} \beta_{i}=1$, then we constructed a reduced model by substituting the last beta by one subtract all the other betas. Then we can rewrite the model to become:

$$
R_{i}=\alpha_{i}+\beta_{i}^{H K} M S C I^{H K}+\cdots+\left(1-\beta_{i}^{H K}-\cdots-\beta_{i}^{T W}\right) M S C I^{T H}+\varepsilon_{i}
$$

After removed the parenthesis and combine the like terms, the model then become:

$$
\text { i. } \quad R_{i}-M S C I^{T H}=\alpha_{i}+\beta_{i}^{H K}\left(M S C I^{H K}-M S C I^{T H}\right)+\cdots+\beta_{i}^{T W}\left(M S C I^{T W}-M S C I^{T H}\right)+\varepsilon_{i}
$$

Since here we only considered one "new risk asset" which is the Small-Cap market returns, the test statistics of exact distribution of the Likelihood ratio test under the null hypothesis is as the following:

$$
H K=\left(\frac{1}{V}-1\right)\left(\frac{T-K-1}{2}\right)
$$

We let $\mathrm{V}$ denote the ratio of the determinant of the maximum likelihood estimator of the error covariance matrix for the unrestricted model (no spanning) to that of the restricted model (spanning). $\mathrm{T}$ is the number of observations and $\mathrm{K}$ is the number of benchmark assets. The test statistic follows an $\mathrm{F}$ distribution with (2, T-K-1) degree of freedom. We applied the same methodology for the Mid-Cap stocks. Result showed in Table 3. To compute the V we used the formula as following:

$$
V=\frac{\sum_{i=1}^{n}(\text { residuals from the unrestricted model })^{2}}{\sum_{i=1}^{n}(\text { residuals from the restricted } \text { model })^{2}}
$$

We found that we rejected the null hypothesizes of the spanning tests of the Mid-Cap stocks for seven out of eleven Asia countries under ten percent significant level, except Hong Kong, China, India, Korea under 5\% of the significant level, where the p-value are 0.243, 0.672, 0.964 and 0.531.Similar result for the spanning tests of the Small-Cap stocks. We rejected eight out of eleven Asia countries under ten percent significant level, except India, Korea, Malaysia and Taiwan, where the p-value are 0.201, 0.396, 0.424 and 0.098 .

From previous discussion, we know that most countries have lower correlation between Small-Cap market returns and U.S. Country market returns or World market returns than Large-Cap market returns. And the result of spanning tests showed that the Small-Cap market returns cannot be spanned by the countries indices. If an investor chooses portfolios based on mean and variance, then the question becomes whether adding a new set of risky assets can allow the investor to improve the minimum-variance frontier from a given set of risky assets.

\subsection{Return-Generating Mechanism for the Cap-based indices}

In order to catch the behavior of the returns generated from the market based indices more precisely, we extended the research to factors of global, local, and idiosyncratic, which affect the cap-based market indices.

We constructed a two factor regression model to estimate the coefficients of global and the country indices for the Small-Cap market returns of each country as following:

$$
R_{i}=\alpha_{i}+\beta_{i}^{W} R^{W}+\beta_{i}^{C} R_{i}^{C}+\varepsilon_{i}
$$

We let $R_{i}$ represent the daily return on the from the i-th country, $R^{W}$ is the daily return on the MSCI the World market index, and $R_{i}^{C}$ is the portion of the $\mathrm{i}$-th country market index return that is uncorrelated to the return on the global market portfolio; which means that $R_{i}^{C}$ is the residual from regressing the i-th country market index return on the MSCI World market index return. $\beta_{i}^{W}$ and $\beta_{i}^{C}$ in equation above denote the coefficients of global and orthogonalized country for the i-th country. In this model, we then can estimate the sensitivities of returns of the cap-based market indices to the global and country-specific factors. Once the coefficients of global and country have been measured, we then decomposed the variance of the cap-based market returns into the following three portions, the portion of the variance attributed to the global factor, the portion attributed to the country factor, and the idiosyncratic risk of the cap-based market returns, which is uncorrelated to either global or country factor. We computed the three proportions of the variance by the following formulas:

(i) Global factor proportion $=\frac{\left(\beta_{i}^{W}\right)^{2} \operatorname{Var}\left(R^{W}\right)}{\operatorname{Var}\left(R_{i}\right)}$ 
(ii) Local factor proportion $=\frac{\left(\beta_{i}^{C}\right)^{2} \operatorname{Var}\left(R_{i}^{C}\right)}{\operatorname{Var}\left(R_{i}\right)}$

(iii) Idiosyncratic factor proportion $=\frac{\operatorname{Var}\left(\varepsilon_{i}\right)}{\operatorname{Var}\left(R_{i}\right)}$

We showed the result of the two factor regressions in Table 4 including the estimate coefficients of the global and country factors and the portions of the variance of the cap-base market returns.

We noticed that all the cap-based market returns in the sample have the statistically significant coefficients of World and country factor with p-value equals 0 , which confirms that the global and the country factor do affect the cap-base market returns.

However, five out of fourteen countries have highest coefficients from Large-Cap market returns; then followed by the coefficients from Mid-Cap market returns. The coefficients from Small-Cap market returns are the lowest. For example, China has the coefficients of the global (country) factor of 0.754 (1.023) for the Large-Cap market return, $0.617(0.854)$ for the Mid-Cap market returns, and $0.452(0.646)$ for the Small-Cap market returns. In five other countries, Indonesia, Korea, Philippine, Singapore and Taiwan, have smaller World coefficient from the Large-Cap than Mid-Cap. For Indonesia, the coefficient of the global factor is 0.530 for the Large-Cap market return, .610 for the Mid-Cap market returns, and 0.533 for the Small-Cap market returns.

The result for variance decompositions, the proportions of the variance for the global, country, and the idiosyncratic factors, are things of noteworthy. Regardless of the country, the idiosyncratic factors proportion is lowest compared with the global and country factors proportions for all the Large-Cap market returns. For example, China Large-Cap market returns has the global factors proportion is $21.2 \%$, country factors proportion is $78.5 \%$, and the idiosyncratic factors proportion $0.3 \%$. As for the Small-Cap market returns, ten out of eleven countries have larger idiosyncratic factors proportion than the global factor, except Korea. From the data, we noticed that for all eleven Asia countries, Small-Cap market returns has the largest proportion for the idiosyncratic factors, followed by the Mid-Cap market returns, then Large-Cap market returns has the lowest among these three market-Cap categories. We then conclude that the Small-Cap market returns are driven more by the idiosyncratic factors than the Large-Cap market returns.

\subsection{Diversification of International Portfolio with Country Market Indices}

In order to assess the benefit of diversification of international portfolio with Small-Cap market indices, it would be useful to examine the benchmark case of international portfolio with the country market indices. We used the data of the MSCI country stock market indices of eleven Asia countries over recent past year (Sep 14, 2011 to Sep 13, 2012) to build a portfolio based on minimum variance frontier. In Table 5 Panel A, the first two columns shows the optimal asset allocation of international portfolios contain the MSCI countries daily returns, With short-sales, the portfolio expected return is $0.0337 \%$ and the standard deviation is $0.7172 \%$. Without short-sales, the optimal portfolio consists of the investing $56.57 \%$ in the Malaysia, $35.13 \%$ in Japan, $6.68 \%$ in India and $1.62 \%$ in Philippines, with an expected return of $0.0323 \%$ and the standard deviation of $0.8822 \%$.

\subsection{The Optimal International Portfolio Allocation}

In order to assess the potential gain of diversification by including the cap-base market returns, we further build international portfolio with the MSCI country and Cap-based market daily returns in Markowitz model; results are presented in Table 5. In Panel B, we compute the optimal global allocation with MSCI countries market daily returns and Small-Cap market daily returns. With short-sales not allowed, the result suggests to invest $38.85 \%$ in Malaysia Country market, $45.84 \%$ in Japan Small-Cap market, $14.62 \%$ in India Small-Cap market, and $0.688 \%$ in Philippines Small-Cap market. By comparing with the portfolio only contains countries market returns and the portfolio with the country and the Small-Cap market returns, we shift about $61 \%$ of the investment from the country market to the Small-Cap market to gain the benefit of reduction risk from $0.8822 \%$ to 0.8117 . In Panel C, with countries and Mid-Cap market returns, the optimal portfolio of developed countries consist of investing $42.82 \%$ in Malaysia Country market and shift $45.12 \%$ to Japan Mid-Cap market and $12.06 \%$ to India Mid-Cap market to reduce the risk to 0.8311. In Panel D, we include Small-Cap and the Mid-Cap market returns in the without short sale portfolio, the result showed that $20 \%$ of the assets will be suggested to invest in the Mid-Cap market, and the about $50 \%$ in the Japan Small-Cap then $16.34 \%$ in India Small-Cap to obtain $0.0022 \%$ return and $0.8814 \%$ risk. From this optimal portfolio, we can see that without Country Market returns; this scenario didn't improve the portfolio that much. The optimal allocation with short-sales, regardless of Mid-Cap markets or Small-Cap markets, introducing Cap markets can reduce risk majorly.

\section{Conclusion}

World markets are becoming more and more globalized and interdependent, and this interdependence has increased the correlations between these markets. International portfolio managers seek to find ways to better diversify away the correlated risk among these interdependent markets. Mid-Cap and Small-Cap stocks in Asia Markets have 
limited international footprints tend to reflect local risks, and therefore share less of a correlation with Large-Cap stocks that share systemic ties to other international firms.

These results are particularly important to international portfolio managers as it provides an alternative investment strategy. Mid-Cap and Small-Cap stocks are relatively isolated from the broader market, and as such provide a damper to any systemic or systematic contingencies that diminish optimum portfolio performance. If international portfolio managers believe that correlations between markets are best reduced by Large-Cap stocks, they may be mistaken. We examined the potential gain of introducing Mid-Cap and Small-Cap stocks as a vehicle for diversification of international portfolios. We found that Mid-Cap and Small-Cap markets have lower correlations not only with World market returns but also with each other. In contrast, Large-Cap funds tend to have relatively high correlations with World market returns and with each other, due to the common exposures to international investors. We also found that eight out of eleven Asia Small-Cap markets cannot be 'spanned' by country stock market indices that are dominated by Large-Cap stocks.

Our results also indicate that when the short sale is allowed, the portfolio contains country indices and Small-Cap markets can reduce the risk majorly; while at the same time, the portfolio contains country indices and Mid-Cap markets can enhance the return more. When short sales are not allowed, introducing Cap markets into portfolio didn't make any significant difference. Overall, our findings indicate that investors can obtain additional gains from international diversification if they consider including Mid-Cap and Small-Cap stocks.

Table 1. Correlations

\begin{tabular}{|c|c|c|c|c|c|c|c|c|c|c|c|}
\hline \multicolumn{12}{|c|}{ Correlations between Country Market Returns } \\
\hline & HONGKONG & JAPAN & SINGAPORE & CHINA & INDIA & INDONESIA & KOREA & MALAYSIA & PHILIPPINES & TAIWAN & THAILAND \\
\hline HONGKONG & 1.000 & 0.539 & 0.748 & 0.897 & 0.554 & 0.591 & 0.671 & 0.560 & 0.520 & 0.608 & 0.617 \\
\hline JAPAN & 0.539 & 1.000 & 0.454 & 0.527 & 0.252 & 0.392 & 0.580 & 0.422 & 0.462 & 0.516 & 0.369 \\
\hline SINGAPORE & 0.748 & 0.454 & 1.000 & 0.745 & 0.631 & 0.630 & 0.666 & 0.633 & 0.454 & 0.603 & 0.624 \\
\hline CHINA & 0.897 & 0.527 & 0.745 & 1.000 & 0.586 & 0.615 & 0.685 & 0.592 & 0.548 & 0.630 & 0.603 \\
\hline INDIA & 0.554 & 0.252 & 0.631 & 0.586 & 1.000 & 0.485 & 0.439 & 0.481 & 0.366 & 0.416 & 0.505 \\
\hline INDONESIA & 0.591 & 0.392 & 0.630 & 0.615 & 0.485 & 1.000 & 0.529 & 0.574 & 0.533 & 0.536 & 0.550 \\
\hline KOREA & 0.671 & 0.580 & 0.666 & 0.685 & 0.439 & 0.529 & 1.000 & 0.589 & 0.502 & 0.718 & 0.487 \\
\hline MALAYSIA & 0.560 & 0.422 & 0.633 & 0.592 & 0.481 & 0.574 & 0.589 & 1.000 & 0.542 & 0.582 & 0.529 \\
\hline PHILIPPINES & 0.520 & 0.462 & 0.454 & 0.548 & 0.366 & 0.533 & 0.502 & 0.542 & 1.000 & 0.533 & 0.462 \\
\hline TAIWAN & 0.608 & 0.516 & 0.603 & 0.630 & 0.416 & 0.536 & 0.718 & 0.582 & 0.533 & 1.000 & 0.472 \\
\hline THAILAND & 0.617 & 0.369 & 0.624 & 0.603 & 0.505 & 0.550 & 0.487 & 0.529 & 0.462 & 0.472 & 1.000 \\
\hline \multicolumn{12}{|c|}{ Correlations between Large-Cap Market Returns } \\
\hline & HONGKONG & JAPAN & SINGAPORE & CHINA & INDIA & INDONESIA & KOREA & MALAYSIA & PHILIPPINES & TAIWAN & THAILAND \\
\hline HONGKONG & 1.000 & 0.527 & 0.737 & 0.888 & 0.550 & 0.565 & 0.658 & 0.525 & 0.484 & 0.595 & 0.614 \\
\hline JAPAN & 0.527 & 1.000 & 0.446 & 0.522 & 0.254 & 0.388 & 0.584 & 0.420 & 0.450 & 0.517 & 0.370 \\
\hline SINGAPORE & 0.737 & 0.446 & 1.000 & 0.734 & 0.626 & 0.604 & 0.652 & 0.602 & 0.418 & 0.594 & 0.612 \\
\hline CHINA & 0.888 & 0.522 & 0.734 & 1.000 & 0.587 & 0.595 & 0.674 & 0.565 & 0.514 & 0.621 & 0.601 \\
\hline INDIA & 0.550 & 0.254 & 0.626 & 0.587 & 1.000 & 0.474 & 0.440 & 0.470 & 0.358 & 0.418 & 0.504 \\
\hline INDONESIA & 0.565 & 0.388 & 0.604 & 0.595 & 0.474 & 1.000 & 0.510 & 0.542 & 0.519 & 0.521 & 0.534 \\
\hline KOREA & 0.658 & 0.584 & 0.652 & 0.674 & 0.440 & 0.510 & 1.000 & 0.569 & 0.481 & 0.712 & 0.476 \\
\hline MALAYSIA & 0.525 & 0.420 & 0.602 & 0.565 & 0.470 & 0.542 & 0.569 & 1.000 & 0.521 & 0.565 & 0.513 \\
\hline PHILIPPINES & 0.484 & 0.450 & 0.418 & 0.514 & 0.358 & 0.519 & 0.481 & 0.521 & 1.000 & 0.515 & 0.444 \\
\hline TAIWAN & 0.595 & 0.517 & 0.594 & 0.621 & 0.418 & 0.521 & 0.712 & 0.565 & 0.515 & 1.000 & 0.471 \\
\hline THAILAND & 0.614 & 0.370 & 0.612 & 0.601 & 0.504 & 0.534 & 0.476 & 0.513 & 0.444 & 0.471 & 1.000 \\
\hline World & 0.457 & 0.276 & 0.592 & 0.461 & 0.479 & 0.340 & 0.430 & 0.363 & 0.249 & 0.362 & 0.433 \\
\hline US & 0.249 & 0.006 & 0.361 & 0.248 & 0.324 & 0.151 & 0.218 & 0.148 & 0.054 & 0.162 & 0.259 \\
\hline \multicolumn{12}{|c|}{ Correlations between Mid-Cap Market Returns } \\
\hline & HONGKONG & JAPAN & SINGAPORE & CHINA & INDIA & INDONESIA & KOREA & MALAYSIA & PHILIPPINES & TAIWAN & THAILAND \\
\hline HONGKONG & 1.000 & 0.523 & 0.679 & 0.843 & 0.493 & 0.595 & 0.623 & 0.607 & 0.526 & 0.579 & 0.507 \\
\hline JAPAN & 0.523 & 1.000 & 0.428 & 0.496 & 0.230 & 0.366 & 0.519 & 0.381 & 0.392 & 0.471 & 0.309 \\
\hline SINGAPORE & 0.679 & 0.428 & 1.000 & 0.670 & 0.565 & 0.623 & 0.639 & 0.648 & 0.445 & 0.549 & 0.551 \\
\hline CHINA & 0.843 & 0.496 & 0.670 & 1.000 & 0.498 & 0.612 & 0.666 & 0.628 & 0.520 & 0.618 & 0.507 \\
\hline INDIA & 0.493 & 0.230 & 0.565 & 0.498 & 1.000 & 0.447 & 0.390 & 0.455 & 0.307 & 0.359 & 0.414 \\
\hline INDONESIA & 0.595 & 0.366 & 0.623 & 0.612 & 0.447 & 1.000 & 0.545 & 0.599 & 0.460 & 0.520 & 0.501 \\
\hline KOREA & 0.623 & 0.519 & 0.639 & 0.666 & 0.390 & 0.545 & 1.000 & 0.591 & 0.444 & 0.677 & 0.458 \\
\hline MALAYSIA & 0.607 & 0.381 & 0.648 & 0.628 & 0.455 & 0.599 & 0.591 & 1.000 & 0.469 & 0.558 & 0.486 \\
\hline PHILIPPINES & 0.526 & 0.392 & 0.445 & 0.520 & 0.307 & 0.460 & 0.444 & 0.469 & 1.000 & 0.457 & 0.368 \\
\hline TAIWAN & 0.579 & 0.471 & 0.549 & 0.618 & 0.359 & 0.520 & 0.677 & 0.558 & 0.457 & 1.000 & 0.397 \\
\hline THAILAND & 0.507 & 0.309 & 0.551 & 0.507 & 0.414 & 0.501 & 0.458 & 0.486 & 0.368 & 0.397 & 1.000 \\
\hline World & 0.388 & 0.277 & 0.563 & 0.420 & 0.424 & 0.376 & 0.435 & 0.365 & 0.249 & 0.337 & 0.406 \\
\hline US & 0.154 & 0.022 & 0.330 & 0.198 & 0.273 & 0.186 & 0.237 & 0.150 & 0.077 & 0.148 & 0.252 \\
\hline \multicolumn{12}{|c|}{ Correlations between Small-Cap Market Returns } \\
\hline & HONGKONG & JAPAN & SINGAPORE & CHINA & INDIA & INDONESIA & KOREA & MALAYSIA & PHILIPPINES & TAIWAN & THAILAND \\
\hline HONGKONG & 1.000 & 0.475 & 0.725 & 0.910 & 0.512 & 0.633 & 0.664 & 0.657 & 0.619 & 0.604 & 0.569 \\
\hline JAPAN & 0.475 & 1.000 & 0.412 & 0.456 & 0.219 & 0.335 & 0.482 & 0.326 & 0.383 & 0.392 & 0.334 \\
\hline SINGAPORE & 0.725 & 0.412 & 1.000 & 0.697 & 0.578 & 0.662 & 0.625 & 0.745 & 0.535 & 0.543 & 0.602 \\
\hline CHINA & 0.910 & 0.456 & 0.697 & 1.000 & 0.508 & 0.598 & 0.643 & 0.642 & 0.586 & 0.600 & 0.527 \\
\hline INDIA & 0.512 & 0.219 & 0.578 & 0.508 & 1.000 & 0.497 & 0.410 & 0.495 & 0.390 & 0.372 & 0.473 \\
\hline INDONESIA & 0.633 & 0.335 & 0.662 & 0.598 & 0.497 & 1.000 & 0.529 & 0.642 & 0.519 & 0.476 & 0.572 \\
\hline KOREA & 0.664 & 0.482 & 0.625 & 0.643 & 0.410 & 0.529 & 1.000 & 0.586 & 0.516 & 0.630 & 0.494 \\
\hline MALAYSIA & 0.657 & 0.326 & 0.745 & 0.642 & 0.495 & 0.642 & 0.586 & 1.000 & 0.532 & 0.529 & 0.541 \\
\hline PHILIPPINES & 0.619 & 0.383 & 0.535 & 0.586 & 0.390 & 0.519 & 0.516 & 0.532 & 1.000 & 0.472 & 0.445 \\
\hline TAIWAN & 0.604 & 0.392 & 0.543 & 0.600 & 0.372 & 0.476 & 0.630 & 0.529 & 0.472 & 1.000 & 0.422 \\
\hline THAILAND & 0.569 & 0.334 & 0.602 & 0.527 & 0.473 & 0.572 & 0.494 & 0.541 & 0.445 & 0.422 & 1.000 \\
\hline World & 0.392 & 0.235 & 0.545 & 0.376 & 0.426 & 0.355 & 0.432 & 0.384 & 0.254 & 0.323 & 0.410 \\
\hline US & 0.165 & 0.006 & 0.299 & 0.161 & 0.275 & 0.164 & 0.232 & 0.185 & 0.069 & 0.147 & 0.234 \\
\hline
\end{tabular}


Table 2. Basic Statistics and Correlations with World and Country Markets

\begin{tabular}{lllllll} 
& Mean & Variance & Skewness & Kurtosis & Corr World & Corr US \\
\cline { 2 - 6 } HONGKONG Large & $0.012 \%$ & 0.0003 & 0.169 & 6.363 & 0.457 & 0.249 \\
JAPAN Large & $-0.016 \%$ & 0.0003 & 0.081 & 5.626 & 0.276 & 0.006 \\
SINGAPORE Large & $0.011 \%$ & 0.0003 & -0.067 & 3.615 & 0.592 & 0.361 \\
CHINA Large & $0.005 \%$ & 0.0005 & 0.370 & 5.927 & 0.461 & 0.248 \\
INDIA Large & $0.008 \%$ & 0.0005 & 0.630 & 9.256 & 0.479 & 0.324 \\
INDONESIA Large & $0.059 \%$ & 0.0005 & 0.076 & 6.727 & 0.340 & 0.151 \\
KOREA Large & $0.030 \%$ & 0.0006 & 0.609 & 18.378 & 0.430 & 0.218 \\
MALAYSIA Large & $0.035 \%$ & 0.0001 & -0.518 & 7.111 & 0.363 & 0.148 \\
PHILIPPINES Large & $0.036 \%$ & 0.0003 & -0.492 & 5.303 & 0.249 & 0.054 \\
TAIWAN Large & $0.008 \%$ & 0.0003 & 0.017 & 2.222 & 0.362 & 0.162 \\
THAILAND Large & $0.051 \%$ & 0.0004 & -0.270 & 5.164 & 0.433 & 0.259
\end{tabular}

\begin{tabular}{lllllll} 
& Mean & Variance & Skewness & Kurtosis & Corr World & Corr US \\
\cline { 2 - 6 } HONG KONG Mid & $0.006 \%$ & 0.0002 & -0.335 & 3.661 & 0.388 & 0.154 \\
JAPAN Mid & $-0.007 \%$ & 0.0002 & 0.009 & 6.114 & 0.277 & 0.022 \\
SINGAPORE Mid & $0.034 \%$ & 0.0003 & 0.175 & 4.277 & 0.563 & 0.330 \\
CHINA Mid & $-0.018 \%$ & 0.0004 & -0.271 & 3.878 & 0.420 & 0.198 \\
INDIA Mid & $0.026 \%$ & 0.0005 & 0.214 & 7.033 & 0.424 & 0.273 \\
INDONESIA Mid & $0.079 \%$ & 0.0005 & -0.082 & 5.357 & 0.376 & 0.186 \\
KOREA Mid & $0.015 \%$ & 0.0006 & 0.295 & 16.309 & 0.435 & 0.237 \\
MALAYSIA Mid & $0.022 \%$ & 0.0002 & -0.489 & 5.684 & 0.365 & 0.150 \\
PHILIPPINES Mid & $0.076 \%$ & 0.0004 & -0.136 & 4.303 & 0.249 & 0.077 \\
TAIWAN Mid & $-0.006 \%$ & 0.0004 & -0.270 & 1.769 & 0.337 & 0.148 \\
THAILAND Mid & $0.085 \%$ & 0.0003 & -0.018 & 4.300 & 0.406 & 0.252
\end{tabular}

\begin{tabular}{lllllll} 
& Mean & Variance & Skewness & Kurtosis & Corr World & Corr US \\
\cline { 2 - 6 } HONGKONG Small & $-0.012 \%$ & 0.0003 & -0.746 & 4.546 & 0.392 & 0.165 \\
JAPAN Small & $-0.001 \%$ & 0.0002 & -0.220 & 6.884 & 0.235 & 0.006 \\
SINGAPORE Small & $0.004 \%$ & 0.0002 & -0.148 & 4.400 & 0.545 & 0.299 \\
CHINA Small & $-0.010 \%$ & 0.0003 & -0.535 & 3.163 & 0.376 & 0.161 \\
INDIA Small & $-0.013 \%$ & 0.0004 & -0.127 & 5.542 & 0.426 & 0.275 \\
INDONESIA Small & $0.040 \%$ & 0.0004 & -0.828 & 7.366 & 0.355 & 0.164 \\
KOREA Small & $0.004 \%$ & 0.0005 & 0.257 & 20.900 & 0.432 & 0.232 \\
MALAYSIA Small & $0.030 \%$ & 0.0002 & -0.616 & 5.969 & 0.384 & 0.185 \\
PHILIPPINES Small & $0.061 \%$ & 0.0003 & -0.432 & 3.117 & 0.254 & 0.069 \\
TAIWAN Small & $0.004 \%$ & 0.0003 & -0.433 & 2.107 & 0.323 & 0.147 \\
THAILAND Small & $0.051 \%$ & 0.0002 & -0.951 & 7.063 & 0.410 & 0.234
\end{tabular}


Table 3A. Spanning Test Results for Mid-Cap Stocks

\begin{tabular}{|c|c|c|c|c|c|c|c|c|c|c|c|c|c|c|}
\hline Beta & Constant & HONGKONG & JAPAN & SINGAPORE & CHINA & INDIA & INDONESIA & KOREA & MALAYSIA & PHILIPPINES & TAIWAN & THAILAND & HK & P-values \\
\hline HONGKONG & 0.000 & 0.638 & 0.057 & -0.037 & $\underline{0.050}$ & -0.007 & 0.037 & -0.022 & 0.135 & 0.091 & $\underline{0.035}$ & -0.010 & 1.416 & 0.243 \\
\hline JAPAN & 0.000 & -0.006 & 0.947 & 0.003 & 0.004 & -0.003 & 0.001 & -0.013 & -0.026 & -0.014 & 0.006 & 0.007 & 43.271 & 0.000 \\
\hline SINGAPORE & 0.000 & -0.044 & 0.009 & 0.943 & $\underline{0.038}$ & 0.007 & $\underline{0.024}$ & 0.021 & 0.056 & 0.042 & -0.036 & 0.002 & 6.894 & 0.001 \\
\hline CHINA & 0.000 & $\underline{0.065}$ & 0.009 & -0.116 & 0.743 & -0.020 & 0.043 & 0.012 & 0.156 & 0.076 & 0.049 & 0.001 & 0.397 & 0.672 \\
\hline INDIA & 0.000 & 0.019 & $\underline{0.040}$ & -0.072 & -0.001 & 0.988 & $\underline{0.034}$ & -0.038 & 0.039 & 0.000 & -0.033 & 0.018 & 0.037 & 0.964 \\
\hline INDONESIA & 0.000 & 0.005 & -0.023 & 0.014 & 0.000 & -0.004 & 0.869 & 0.021 & 0.112 & 0.019 & 0.041 & $\underline{0.044}$ & 6.735 & 0.001 \\
\hline KOREA & 0.000 & 0.014 & -0.038 & -0.040 & 0.011 & -0.006 & 0.018 & 0.952 & $\underline{0.053}$ & -0.008 & 0.023 & 0.045 & 0.632 & 0.531 \\
\hline MALAYSIA & 0.000 & 0.005 & -0.019 & 0.036 & 0.012 & -0.004 & $\underline{0.019}$ & 0.013 & 0.956 & 0.011 & 0.004 & -0.001 & $\underline{3.025}$ & 0.049 \\
\hline PHILIPPINES & 0.000 & -0.040 & 0.010 & $\underline{0.069}$ & 0.030 & -0.012 & -0.038 & -0.006 & -0.027 & 1.093 & 0.033 & -0.001 & 7.101 & 0.001 \\
\hline TAIWAN & 0.000 & -0.045 & 0.009 & -0.006 & 0.021 & 0.003 & -0.003 & 0.005 & $\underline{0.043}$ & -0.026 & 1.072 & 0.005 & 9.688 & 0.000 \\
\hline THAILAND & 0.000 & -0.093 & -0.006 & $\underline{0.056}$ & -0.018 & -0.018 & 0.004 & $\underline{0.037}$ & 0.039 & 0.035 & -0.018 & 0.850 & 14.196 & 0.000 \\
\hline \multicolumn{15}{|c|}{ Table 3A. Spanning Test Results for Small-Cap Stocks } \\
\hline Beta & Constant & HONGKONG & JAPAN & SINGAPORE & CHINA & INDIA & INDONESIA & KOREA & MALAYSIA & PHILIPPINES & TAIWAN & THAILAND & HK & P-Value \\
\hline HONGKONG & 0.000 & 0.315 & 0.035 & -0.085 & 0.228 & -0.006 & 0.047 & 0.021 & 0.204 & 0.105 & 0.080 & -0.002 & 3.226 & 0.040 \\
\hline JAPAN & 0.000 & -0.015 & 0.879 & -0.013 & 0.008 & -0.009 & 0.012 & -0.035 & -0.042 & -0.011 & -0.002 & $\underline{0.020}$ & 89.986 & 0.000 \\
\hline SINGAPORE & 0.000 & -0.063 & 0.057 & 0.534 & 0.029 & 0.000 & 0.059 & 0.008 & 0.247 & 0.005 & -0.006 & 0.029 & 13.422 & 0.000 \\
\hline CHINA & 0.000 & 0.089 & $\underline{0.036}$ & -0.128 & 0.493 & 0.004 & $\underline{0.026}$ & 0.010 & 0.184 & 0.067 & 0.094 & -0.017 & 16.945 & 0.000 \\
\hline INDIA & 0.000 & 0.084 & 0.039 & -0.032 & -0.036 & 0.823 & 0.034 & -0.037 & 0.070 & 0.021 & -0.034 & 0.024 & 1.606 & 0.201 \\
\hline INDONESIA & 0.000 & 0.062 & -0.005 & 0.048 & -0.005 & 0.015 & 0.699 & -0.059 & 0.200 & 0.021 & 0.059 & 0.053 & 4.305 & 0.014 \\
\hline KOREA & 0.000 & 0.011 & 0.008 & -0.058 & -0.001 & -0.008 & 0.045 & 0.846 & 0.030 & 0.012 & 0.017 & 0.064 & 0.926 & 0.396 \\
\hline MALAYSIA & 0.000 & 0.011 & $\underline{-0.026}$ & 0.088 & 0.009 & -0.007 & 0.048 & 0.012 & 0.826 & -0.022 & 0.018 & 0.019 & 0.857 & 0.424 \\
\hline PHILIPPINES & 0.000 & 0.037 & 0.019 & -0.034 & 0.006 & 0.006 & -0.001 & 0.044 & 0.145 & 0.691 & 0.015 & 0.002 & 3.425 & 0.033 \\
\hline TAIWAN & 0.000 & -0.029 & 0.009 & -0.005 & 0.014 & 0.021 & $\underline{-0.029}$ & -0.011 & $\underline{0.057}$ & -0.010 & 0.938 & -0.007 & 2.321 & 0.098 \\
\hline THAILAND & 0.000 & 0.034 & 0.034 & -0.008 & -0.065 & 0.020 & 0.037 & -0.003 & 0.068 & 0.014 & 0.020 & 0.648 & 734.092 & 0.000 \\
\hline
\end{tabular}

Tble 4. Regression and Proportion of Global and Country Factors

\begin{tabular}{|c|c|c|c|c|c|c|}
\hline & & World beta & country beta & Global Factor & Country Factor & ID factor \\
\hline \multirow{3}{*}{ CHINA } & small & 0.452 & 0.646 & $14.2 \%$ & $58.2 \%$ & $27.6 \%$ \\
\hline & Mid & 0.617 & 0.854 & $17.6 \%$ & $67.7 \%$ & $14.6 \%$ \\
\hline & Large & 0.754 & 1.023 & $21.2 \%$ & $78.5 \%$ & $0.3 \%$ \\
\hline \multirow{3}{*}{ HONG KONG } & small & 0.446 & 0.759 & $15.4 \%$ & $51.2 \%$ & $33.4 \%$ \\
\hline & Mid & 0.430 & 0.821 & $15.0 \%$ & $63.1 \%$ & $21.9 \%$ \\
\hline & Large & 0.570 & 1.032 & $20.9 \%$ & $78.6 \%$ & $0.5 \%$ \\
\hline \multirow{3}{*}{ INDIA } & small & 0.620 & 0.852 & $18.2 \%$ & $63.6 \%$ & $18.2 \%$ \\
\hline & Mid & 0.678 & 0.988 & $18.0 \%$ & $70.9 \%$ & $11.1 \%$ \\
\hline & Large & 0.745 & 1.002 & $22.9 \%$ & $76.7 \%$ & $0.3 \%$ \\
\hline \multirow{3}{*}{ INDONESIA } & small & 0.533 & 0.819 & $12.6 \%$ & $61.4 \%$ & $26.0 \%$ \\
\hline & Mid & 0.610 & 0.939 & $14.2 \%$ & $69.4 \%$ & $16.4 \%$ \\
\hline & Large & 0.530 & 1.012 & $11.5 \%$ & $87.3 \%$ & $1.1 \%$ \\
\hline \multirow{3}{*}{ JAPAN } & small & 0.243 & 0.838 & $5.5 \%$ & $80.6 \%$ & $13.9 \%$ \\
\hline & Mid & 0.304 & 0.927 & $7.7 \%$ & $87.3 \%$ & $5.0 \%$ \\
\hline & Large & 0.323 & 1.017 & $7.6 \%$ & $92.2 \%$ & $0.2 \%$ \\
\hline \multirow{3}{*}{ KOREA } & small & 0.717 & 0.874 & $18.7 \%$ & $67.4 \%$ & $13.9 \%$ \\
\hline & Mid & 0.767 & 0.968 & $18.9 \%$ & $73.1 \%$ & $8.0 \%$ \\
\hline & Large & 0.750 & 1.007 & $18.5 \%$ & $81.0 \%$ & $0.4 \%$ \\
\hline \multirow{3}{*}{ MALAYSIA } & small & 0.357 & 0.957 & $14.7 \%$ & $60.6 \%$ & $24.7 \%$ \\
\hline & Mid & 0.329 & 1.032 & $13.3 \%$ & $74.5 \%$ & $12.2 \%$ \\
\hline & Large & 0.294 & 0.992 & $13.2 \%$ & $85.7 \%$ & $1.1 \%$ \\
\hline \multirow{3}{*}{ PHILIPPINES } & small & 0.296 & 0.795 & $6.5 \%$ & $61.8 \%$ & $31.7 \%$ \\
\hline & Mid & 0.375 & 1.095 & $6.2 \%$ & $70.2 \%$ & $23.6 \%$ \\
\hline & Large & 0.291 & 0.956 & $6.2 \%$ & $88.9 \%$ & $4.9 \%$ \\
\hline \multirow{3}{*}{ SINGAPORE } & small & 0.551 & 0.693 & $29.7 \%$ & $44.2 \%$ & $26.2 \%$ \\
\hline & Mid & 0.733 & 1.019 & $31.7 \%$ & $57.8 \%$ & $10.5 \%$ \\
\hline & Large & 0.716 & 0.995 & $35.1 \%$ & $63.9 \%$ & $1.0 \%$ \\
\hline \multirow{3}{*}{ TAIWAN } & small & 0.406 & 0.925 & $10.4 \%$ & $67.6 \%$ & $22.0 \%$ \\
\hline & Mid & 0.458 & 1.076 & $11.4 \%$ & $78.6 \%$ & $10.1 \%$ \\
\hline & Large & 0.430 & 0.984 & $13.1 \%$ & $86.2 \%$ & $0.6 \%$ \\
\hline \multirow{3}{*}{ THAILAND } & small & 0.433 & 0.684 & $16.8 \%$ & $59.6 \%$ & $23.6 \%$ \\
\hline & Mid & 0.520 & 0.838 & $16.5 \%$ & $60.8 \%$ & $22.7 \%$ \\
\hline & Large & 0.591 & 1.029 & $18.7 \%$ & $80.5 \%$ & $0.8 \%$ \\
\hline
\end{tabular}


Table 5. Optimal Portfolio Allocation of Developed Countries

\begin{tabular}{|c|c|c|c|c|c|c|c|c|}
\hline & $\begin{array}{l}\text { Panel A } \\
\text { Country }\end{array}$ & & $\begin{array}{l}\text { Panel B } \\
\text { Country- }\end{array}$ & nall Cap & $\begin{array}{l}\text { Panel C } \\
\text { Country- }\end{array}$ & Iid Cap & $\begin{array}{l}\text { Panel D } \\
\mathrm{Mid}+\mathrm{Sm}\end{array}$ & \\
\hline Short Sales & Without & With & Without & With & Without & With & Without & With \\
\hline HONGKONG & $0.00 \%$ & $39.91 \%$ & $0.00 \%$ & $35.62 \%$ & $0.00 \%$ & $34.81 \%$ & & \\
\hline JAPAN & $35.13 \%$ & $38.10 \%$ & $0.00 \%$ & $-8.42 \%$ & $0.00 \%$ & $-34.19 \%$ & & \\
\hline SINGAPORE & $0.00 \%$ & $2.71 \%$ & $0.00 \%$ & $-10.67 \%$ & $0.00 \%$ & $-24.11 \%$ & & \\
\hline CHINA & $0.00 \%$ & $-41.03 \%$ & $0.00 \%$ & $-29.35 \%$ & $0.00 \%$ & $-6.91 \%$ & & \\
\hline INDIA & $6.68 \%$ & $12.55 \%$ & $0.00 \%$ & $-9.11 \%$ & $0.00 \%$ & $-3.84 \%$ & & \\
\hline INDONESIA & $0.00 \%$ & $-6.74 \%$ & $0.00 \%$ & $11.19 \%$ & $0.00 \%$ & $-1.29 \%$ & & \\
\hline KOREA & $0.00 \%$ & $-25.84 \%$ & $0.00 \%$ & $-24.27 \%$ & $0.00 \%$ & $-21.85 \%$ & & \\
\hline MALASIA & $56.57 \%$ & $65.76 \%$ & $38.85 \%$ & $66.31 \%$ & $42.82 \%$ & $64.59 \%$ & & \\
\hline PHILIPPINES & $1.62 \%$ & $8.60 \%$ & $0.00 \%$ & $-10.21 \%$ & $0.00 \%$ & $10.98 \%$ & & \\
\hline TAIWAN & $0.00 \%$ & $11.56 \%$ & $0.00 \%$ & $5.69 \%$ & $0.00 \%$ & $14.62 \%$ & & \\
\hline THAILAND & $0.00 \%$ & $-5.59 \%$ & $0.00 \%$ & $-12.87 \%$ & $0.00 \%$ & $-10.88 \%$ & & \\
\hline HONGKONG Mid & & & & & $0.00 \%$ & $13.55 \%$ & $0.00 \%$ & $26.13 \%$ \\
\hline JAPAN Mid & & & & & $45.12 \%$ & $71.01 \%$ & $2.94 \%$ & $8.88 \%$ \\
\hline SINGAPORE Mid & & & & & $0.00 \%$ & $25.56 \%$ & $0.00 \%$ & $0.14 \%$ \\
\hline CHINA Mid & & & & & $0.00 \%$ & $-28.80 \%$ & $0.00 \%$ & $-49.83 \%$ \\
\hline INDIA Mid & & & & & $12.06 \%$ & $15.79 \%$ & $1.12 \%$ & $-1.19 \%$ \\
\hline INDONESIA Mid & & & & & $0.00 \%$ & $-3.14 \%$ & $0.00 \%$ & $7.99 \%$ \\
\hline KOREA Mid & & & & & $0.00 \%$ & $2.50 \%$ & $0.00 \%$ & $-21.20 \%$ \\
\hline MALASIA Mid & & & & & $0.00 \%$ & $-14.24 \%$ & $15.90 \%$ & $35.88 \%$ \\
\hline PHILIPPINES Mid & & & & & $0.00 \%$ & $-4.58 \%$ & $0.00 \%$ & $-0.33 \%$ \\
\hline TAIWAN Mid & & & & & $0.00 \%$ & $-5.62 \%$ & $0.00 \%$ & $-16.66 \%$ \\
\hline THAILAND Mid & & & & & $0.00 \%$ & $6.04 \%$ & $0.00 \%$ & $-4.75 \%$ \\
\hline HONGKONG Small & & & $0.00 \%$ & $-21.54 \%$ & & & $0.00 \%$ & $-6.02 \%$ \\
\hline JAPAN Small & & & $45.84 \%$ & $45.70 \%$ & & & $49.81 \%$ & $31.25 \%$ \\
\hline SINGAPORE Small & & & $0.00 \%$ & $22.74 \%$ & & & $4.73 \%$ & $9.17 \%$ \\
\hline CHINA Small & & & $0.00 \%$ & $17.83 \%$ & & & $0.00 \%$ & $42.15 \%$ \\
\hline INDIA Small & & & $14.62 \%$ & $20.78 \%$ & & & $16.34 \%$ & $13.48 \%$ \\
\hline INDONESIA Small & & & $0.00 \%$ & $-23.85 \%$ & & & $0.00 \%$ & $-20.36 \%$ \\
\hline KOREA Small & & & $0.00 \%$ & $6.20 \%$ & & & $0.00 \%$ & $2.78 \%$ \\
\hline MALASIA Small & & & $0.00 \%$ & $-17.45 \%$ & & & $0.00 \%$ & $-2.39 \%$ \\
\hline PHILIPPINES Small & & & $0.688 \%$ & $18.35 \%$ & & & $4.89 \%$ & $7.56 \%$ \\
\hline TAIWAN Small & & & $0.00 \%$ & $76.50 \%$ & & & $0.00 \%$ & $23.62 \%$ \\
\hline THAILAND Small & & & $0.00 \%$ & $16.57 \%$ & & & $4.27 \%$ & $13.71 \%$ \\
\hline Expected Returns & $0.0323 \%$ & $0.0337 \%$ & $0.0092 \%$ & $0.0197 \%$ & $0.0218 \%$ & $0.0534 \%$ & $0.0022 \%$ & $0.0363 \%$ \\
\hline Standard Deviation & $0.8822 \%$ & $0.7172 \%$ & $0.8117 \%$ & $0.6022 \%$ & $0.8311 \%$ & $0.6276 \%$ & $0.8814 \%$ & $0.5959 \%$ \\
\hline
\end{tabular}




\section{References}

Brooks, R., \& Del Negro, M. (2006). Firm-Level Evidence on International Stock Market Comovement. Review of Finance, 10(1), 69-98. http://dx.doi.org/10.1007/s10679-006-6979-1

Eun, Cheol S., Huang, Wei., Lai, Sandy (2008). International Diversification with Large- and Small- Cap Stocks. Journal of Financial and Quantitative Analysis, 43(2), 489-524. http://dx.doi.org/10.1017/S0022109000003604

Ferreira, M. A., \& Matos, P. R. (2008). The Colors of Investors' Money: The Role of Institutional Investors Around the World. Journal of Financial Economics, 88(3), 499-533. http://dx.doi.org/10.1016/j.jfineco.2007.07.003

Foerster, S. R., \& Karoly, G. A. (1999). The Effects of Market Segmentation and Investor Recognition on Asset Prices: Evidence from Foreign Stocks Listing in the United States. Journal of Finance, 54(3), 981-1013. http://dx.doi.org/10.1111/0022-1082.00134

Goetzmann, W. N., Lingfeng, L., \& Rouwenhorst, K. G. (2005). Long-Term Global Market Correlations. Journal of Business, 78(1), 1-38. http://dx.doi.org/10.1086/426518

Grubel, H. G. (1968). Internationally Diversified Portfolios: Welfare Gains and Capital Flows. American Economic Review, 58(5), 1299-1314.

Huberman, G. (2001). Familiarity Breeds Investment. Review of Financial Studies, 14(3), 659-680. http://dx.doi.org/10.1093/rfs/14.3.659

Huberman, G. U. R., \& Kandel, S. (1987). Mean-Variance Spanning. Journal of Finance, 42(4), 873-888. http://dx.doi.org/10.1111/j.1540-6261.1987.tb03917.x

Kan, R., \& Zhou, G. (2012). Tests of Mean-Variance Spanning. Annals of Economics and Finance, 13 (1), 139-187.

Kang, J.-K., \& Stulz, R. M. (1997). Why is there a home bias? An analysis of foreign portfolio equity ownership in Japan. Journal of Financial Economics, 46(1), 3-28. http://dx.doi.org/10.1016/S0304-405X(97)00023-8

Levy, H., \& Sarnat, M. (1970). International Diversification of Investment Portfolios. American Economic Review, 60(4), 668-675.

Longin, F., \& Solnik, B. (1995). Is the correlation in international equity returns constant: 1960-1990? Journal of International Money and Finance, 14(1), 3-26. http://dx.doi.org/10.1016/0261-5606(94)00001-H

Markowitz, H. M. (1991). Foundations of Portfolio Theory. Journal of Finance, 46 (2), 469-477. http://dx.doi.org/10.1111/j.1540-6261.1991.tb02669.x

Solnik, B. H. (1974). Why Not Diversify International Rather Than Domestically? Financial Analysts Journal, 30(4), $48-52+54$. 